\title{
Changes in Ultraviolet Radiation Exposure to the Ocular Region: A Population-Based Study
}

\author{
Ezekiel Weis ${ }^{1,2, *}$ (), Sebastian Q. Vrouwe ${ }^{1}$, David B. LeBaron ${ }^{1}$, Matthew B. Parliament ${ }^{3}$, \\ Jerry Shields ${ }^{4}$ and Carol L. Shields ${ }^{4}$ (D) \\ 1 Department of Ophthalmology, Faculty of Medicine and Dentistry, University of Alberta, Edmonton, \\ AB T5H 3V9, Canada; svrouwe@hotmail.com (S.Q.V.); davidlebaron@gmail.com (D.B.L.) \\ 2 Division of Ophthalmology, Department of Surgery, University of Calgary, Calgary, AB T2V 4R6, Canada \\ 3 Division of Radiation Oncology, Faculty of Medicine and Dentistry, University of Alberta, Edmonton, \\ AB T6G 1Z2, Canada; matthew.parliament@albertahealthservices.ca \\ 4 Ocular Oncology Service, Wills Eye Hospital, Thomas Jefferson University, Philadelphia, PA 19107, USA; \\ jerryshields@gmail.com (J.S.); carolshields@gmail.com (C.L.S.) \\ * Correspondence: ezekiel_weis@post.harvard.edu; Tel.: +1-780-735-4932
}

Received: 28 February 2019; Accepted: 15 May 2019; Published: 24 May 2019

\begin{abstract}
In contrast to the well-established association between ultraviolet radiation (UVR) exposure and skin cancers, the relationship between UVR and uveal malignant melanoma (UM) remains controversial. To address this controversy, we evaluated the incidence rates of cutaneous malignancies in the eyelids as a proxy for UVR exposure in the ocular region using a population-based cancer registry. Overall, 74,053 cases of eyelid basal cell carcinoma (BCC) and 7890 cases of melanoma over a 26-year period (1982-2007) were analyzed. The incidence of eyelid basal cell carcinoma and uveal melanoma remained stable, whereas other cutaneous areas demonstrated an increase in the rates. A comparability test demonstrated that $\mathrm{BCC}$ incidence trends were significantly different between the eyelid versus both chronically exposed (males $p=0.001$; females $p=0.01$ ) and intermittently exposed skin (males and females, $p=0.0002$ ), as well as the skin of the face (males $p=0.002$; females $p=0.02$ ). Similarly, melanoma trends were significantly different between the UM group versus both chronically exposed cutaneous melanoma (CM) (males $p=0.001$; females $p=0.04$ ) and intermittently exposed $\mathrm{CM}$ (males $p=0.005$ ), as well as facial skin CM (males and females $p=0.0002)$. The discrepancy of cancer incidence between tumors in the peri-ocular region versus the rest of the body suggests that the peri-ocular region might have a different or unique exposure pattern to ultraviolet radiation.
\end{abstract}

Keywords: ocular tumors; cutaneous melanoma; skin cancer; basal cell carcinoma; ultraviolet radiation; uveal melanoma; eye exposure

\section{Introduction}

Uveal (intra-ocular) malignant melanoma is the most common primary intra-ocular malignancy, and poses a significant risk of both vision loss and death, with up to $50 \%$ of patients dying of their disease [1,2]. It is also the second most common location for malignant melanoma to develop, after the skin [3,4]. Despite recent advances in treatment that often allow preservation of the eye (epi-scleral plaque brachytherapy, proton beam radiotherapy, stereotactic radiotherapy, local resection, and transpupillary thermotherapy) [5], there has been no improvement in survival outcomes $[2,6]$. This highlights the importance of understanding the underlying etiology of uveal malignant melanoma (UM) in order to best direct primary prevention.

There is a well-established causal link between ultraviolet radiation (UVR) exposure and both melanoma and non-melanoma skin cancers. [7-10] However, its role in the etiology of UM 
remains highly controversial [11-21]. In addition to sharing the same underlying malignant cell, the neural-crest-derived melanocyte, there are significant similarities in the high-risk phenotype for cutaneous malignancies and uveal melanoma, such as light-colored skin, the presence of nevi, and light-colored eyes [18-24]. Furthermore, incidence rates of uveal melanoma have been shown to decrease as skin pigmentation increases [25]. Other UV exposure factors such as latitude have demonstrated inconsistent results, with a meta-analysis of five articles demonstrating no significant association ( $\mathrm{OR}=1.08,95 \% \mathrm{CI} 0.67-1.74)$ [16]. Although the anterior segment (cornea, aqueous humor, and lens) absorbs the majority of UVR striking the eye, photochemical damage can still occur in the choroid [26]. Several studies assessing UM have not demonstrated UV signature mutations and significant differences in mutations between CM, conjunctival melanoma, and UM [27-30]. However, when controlling for intra-ocular location and its relation to UV exposure, UV signature genetic changes have been found in posterior uveal melanomas [31]. In addition, less common non-classical mutations found in uveal melanoma may be related to UV exposure [32]. The rising incidence of cutaneous melanoma (CM) $[11,12,33,34]$ that accompanied changes in social/behavioral patterns resulting in intensifying sun exposure is in direct contrast to the incidence of UM that has been found to be stable [11,12,35-37] or decreasing over the same period [38,39]. This difference in incidence rates is one of the strongest criticisms of UVR as a causative factor in UM. Although these trends are indeed divergent, meaningful conclusions based on this observation must account for anatomical locations of lesions as well as their theoretically variable exposure patterns. Furthermore, characterizing the type of UVR exposure is important, as it has been shown that its pattern is critical in the development of CM whereby intermittent or recreational exposure, sunburns, childhood exposure, and chronic occupational exposure have variable associations [14,23,40,41].

This study was therefore designed to evaluate the changes in UVR exposure to the ocular region using BCC incidence as a proxy for UV exposure. Changes in incidence rates of basal cell carcinoma (BCC) of the eyelid - a common tumor with a well-described association with UVR-are used as a surrogate marker for changes in UVR exposure to the ocular region. These eyelid BCC rates are then formally contrasted to the rates of UM in an attempt to evaluate previously held notions on the association of UVR and UM. CM of the eyelid could not be used for this purpose, as its rarity would preclude robust statistical analysis.

\section{Results}

A total of 81,943 tumors (74,053 BCC and 7890 malignant melanoma) were identified over a 26-year period spanning 1 January 1982 to 31 December 2007. Of the BCC cases, 39,029 (52.7\%) occurred in males, and 35,024 (47.3\%) in females. Of the malignant melanoma (CM and UM) cases, 3891 (49.3\%) occurred in males, and $3999(50.7 \%)$ in females.

\subsection{Age-Standardized Incidence Rates}

Table 1 shows the average age-standardized incidence rates (ASIRs) of BCC and melanoma for four anatomical groupings (eyelid, chronically exposed skin, face, and intermittently exposed skin). For BCC, chronically UV exposed skin exhibited the largest average ASIR. Conversely, for melanoma, intermittently UV exposed skin displayed the largest average ASIR. Specifically, for peri-ocular tumors, the ASIR (per 100,000) for BCC of the eyelid was $6.72 \pm 0.83$ in males and $5.71 \pm 0.70$ in females, and for $\mathrm{UM}, 0.49 \pm 0.21$ in males and $0.46 \pm 0.19$ in females.

\subsection{Incidence Trends}

Table 2 shows trends in tumor incidence based on the average annual percent change (AAPC) derived from the underlying join point models of best fit. The incidence of BCC remained stable in the eyelid over the study period in both males and females. By contrast, significant upward trends in BCC incidence were observed in all other skin sites (chronically exposed skin, face, and intermittently exposed skin). The AAPC could not be calculated for CM of the eyelid due to small sample size. 
Table 1. Average age-standardized incidence rates (ASIRs) for ophthalmic and non-ophthalmic basal cell carcinoma and melanoma, 1982-2007.

\begin{tabular}{ccccccc}
\hline \multirow{2}{*}{ Anatomical Grouping } & \multicolumn{2}{c}{ Males } & \multicolumn{2}{c}{ Females } & \multicolumn{2}{c}{ Combined } \\
\cline { 2 - 7 } & $n$ & $\begin{array}{c}\text { Average } \\
\text { ASIR } \pm \text { SE }\end{array}$ & $n$ & $\begin{array}{c}\text { Average } \\
\text { ASIR } \pm \text { SE }\end{array}$ & $n$ & $\begin{array}{c}\text { Average } \\
\text { ASIR } \pm \text { SE }\end{array}$ \\
\hline \multicolumn{7}{c}{ Basal cell carcinoma } \\
\hline Eyelid & 1867 & $6.72 \pm 0.83$ & 1844 & $5.71 \pm 0.70$ & 3711 & $6.13 \pm 0.53$ \\
\hline Chronically exposed skin & 27,934 & $102.21 \pm 3.29$ & 24,819 & $77.52 \pm 2.58$ & 52,753 & $88.41 \pm 2.03$ \\
\hline Face & 20,803 & $76.11 \pm 2.84$ & 20,296 & $63.56 \pm 2.34$ & 41,099 & $69.05 \pm 1.80$ \\
\hline Intermittently exposed skin & 9228 & $29.91 \pm 1.65$ & 8361 & $24.15 \pm 1.37$ & 17,589 & $26.69 \pm 1.05$ \\
\hline \multicolumn{7}{c}{ Melanoma } \\
\hline Uvea & 137 & $0.49 \pm 0.21$ & 144 & $0.46 \pm 0.19$ & 288 & $0.47 \pm 0.14$ \\
\hline Eyelid & 12 & $0.04 \pm 0.04$ & 18 & $0.05 \pm 0.04$ & 30 & $0.04 \pm 0.04$ \\
\hline Chronically exposed skin & 905 & $3.33 \pm 0.60$ & 573 & $1.71 \pm 0.37$ & 1478 & $2.42 \pm 0.33$ \\
\hline Face & 464 & $1.81 \pm 0.45$ & 372 & $1.13 \pm 0.30$ & 836 & $1.42 \pm 0.26$ \\
\hline Intermittently exposed skin & 2849 & $8.68 \pm 0.86$ & 3282 & $9.36 \pm 0.86$ & 6131 & $8.99 \pm 0.61$ \\
\hline
\end{tabular}

Table 2. Incidence trends and the average annual percent change (AAPC) for ophthalmic and non-ophthalmic basal cell carcinoma and melanoma, 1982-2007.

\begin{tabular}{cllll}
\hline \multirow{2}{*}{ Anatomical Grouping } & \multicolumn{2}{c}{ Males } & \multicolumn{2}{c}{ Females } \\
\cline { 2 - 5 } & \multicolumn{1}{c}{ Trend } & AAPC $(95 \%$ CI $)$ & Trend & AAPC (95\% CI) \\
\hline Eyelid & Stable & $-0.4(-1.1$ to 0.4$)$ & Stable & $0.6(-0.1$ to 1.2$)$ \\
\hline Chronically exposed skin & Increasing & $1.8^{*}(0.9$ to 2.8$)$ & Increasing & $1.7^{*}(1.1$ to 2.4$)$ \\
\hline Face & Increasing & $1.4 *(0.7$ to 2.1$)$ & Increasing & $1.7^{*}(0.9$ to 2.5$)$ \\
\hline Intermittently exposed skin & Increasing & $6.3 *(5.1$ to 7.6$)$ & Increasing & $6.4^{*}(5.2$ to 7.7$)$ \\
\hline Uvea & & Melanoma & \\
\hline Eyelid & Stable & $-1.4(-3.6$ to 0.8$)$ & Stable & $-0.9(-2.9$ to 1.2$)$ \\
\hline Chronically exposed skin & Increasing & $3.0 *(1.9$ to 4.1$)$ & Increasing & $2.2 *(0.5$ to 3.9$)$ \\
\hline Face & Increasing & $2.4 *(1.0$ to 3.8$)$ & Stable & $2.1(-0.0$ to 4.3$)$ \\
\hline Intermittently exposed skin & Increasing & $3.2 *(1.9$ to 4.5$)$ & Increasing & $2.0 *(0.6$ to 3.3$)$ \\
\hline
\end{tabular}

$\S$ Unable to calculate due to low numbers; ${ }^{*}$ Statistically significant difference.

A similar pattern of trends was observed for melanoma; the incidence of UM remained stable in both males and females, while significant positive trends were observed for CM in chronically and intermittently exposed skin. For CM in the facial skin, a statistically significant increase was seen in males, and a borderline increasing trend in incidence was seen in females $(2.1 \%, 95 \%$ CI $0.0-4.3)$.

\subsection{Comparability Test}

Table 3 shows the results of the test of parallelism between anatomical regions, comparing peri-ocular/ocular (eyelid and uvea) and extra-ocular tumor incidence. BCC carcinoma change in incidence was significantly different than all other locations. Tests of parallelism comparing incidence trends for the eyelid versus other cutaneous regions revealed significantly different rates of change for chronically exposed skin (Figure 1: males $p=0.001$; females $p=0.01$ ), the face (Figure 1: males $p=0.002$ and females $p=0.02$ ), and intermittently exposed skin (Figure 1: males $p=0.0002$; females $p=0.0002$ ). 
Table 3. Test of parallelism between anatomic groupings for basal cell carcinoma and melanoma, 1982-2007.

\begin{tabular}{|c|c|c|c|}
\hline \multicolumn{2}{|c|}{ Test of Parallelism } & \multicolumn{2}{|c|}{ Result } \\
\hline Group 1 & Group 2 & Males & Females \\
\hline \multicolumn{4}{|c|}{ Basal cell carcinoma } \\
\hline \multirow[t]{3}{*}{ Eyelid vs. } & Chronically exposed skin & ${ }^{*}$ Not parallel $(p=0.001)$ & ${ }^{*}$ Not parallel $(p=0.01)$ \\
\hline & Face & ${ }^{*}$ Not parallel $(p=0.002)$ & ${ }^{*}$ Not parallel $(p=0.02)$ \\
\hline & Intermittently exposed skin & ${ }^{*}$ Not parallel $(p=0.0002)$ & ${ }^{*}$ Not parallel $(p=0.0002)$ \\
\hline Chronically exposed skin vs. & Intermittently exposed skin & ${ }^{*}$ Not parallel $(p=0.0002)$ & ${ }^{*}$ Not parallel $(p=0.0002)$ \\
\hline \multicolumn{4}{|c|}{ Melanoma } \\
\hline \multirow[t]{3}{*}{ Uvea vs. } & Chronically exposed skin & ${ }^{*}$ Not parallel $(p=0.001)$ & ${ }^{*}$ Not parallel $(p=0.04)$ \\
\hline & Face & ${ }^{*}$ Not parallel $(p=0.002)$ & ${ }^{*}$ Not parallel $(p=0.03)$ \\
\hline & Intermittently exposed skin & ${ }^{*}$ Not parallel $(p=0.005)$ & Parallel $(p=0.06)$ \\
\hline Chronically exposed skin vs. & Intermittently exposed skin & Parallel $(p=0.81)$ & Parallel $(p=0.46)$ \\
\hline \multicolumn{4}{|c|}{ Inter-ophthalmic } \\
\hline Uveal malignant melanoma vs. & Eyelid basal cell carcinoma & Parallel $(p=0.08)$ & Parallel $(p=0.24)$ \\
\hline
\end{tabular}

* Statistically significant change over time.
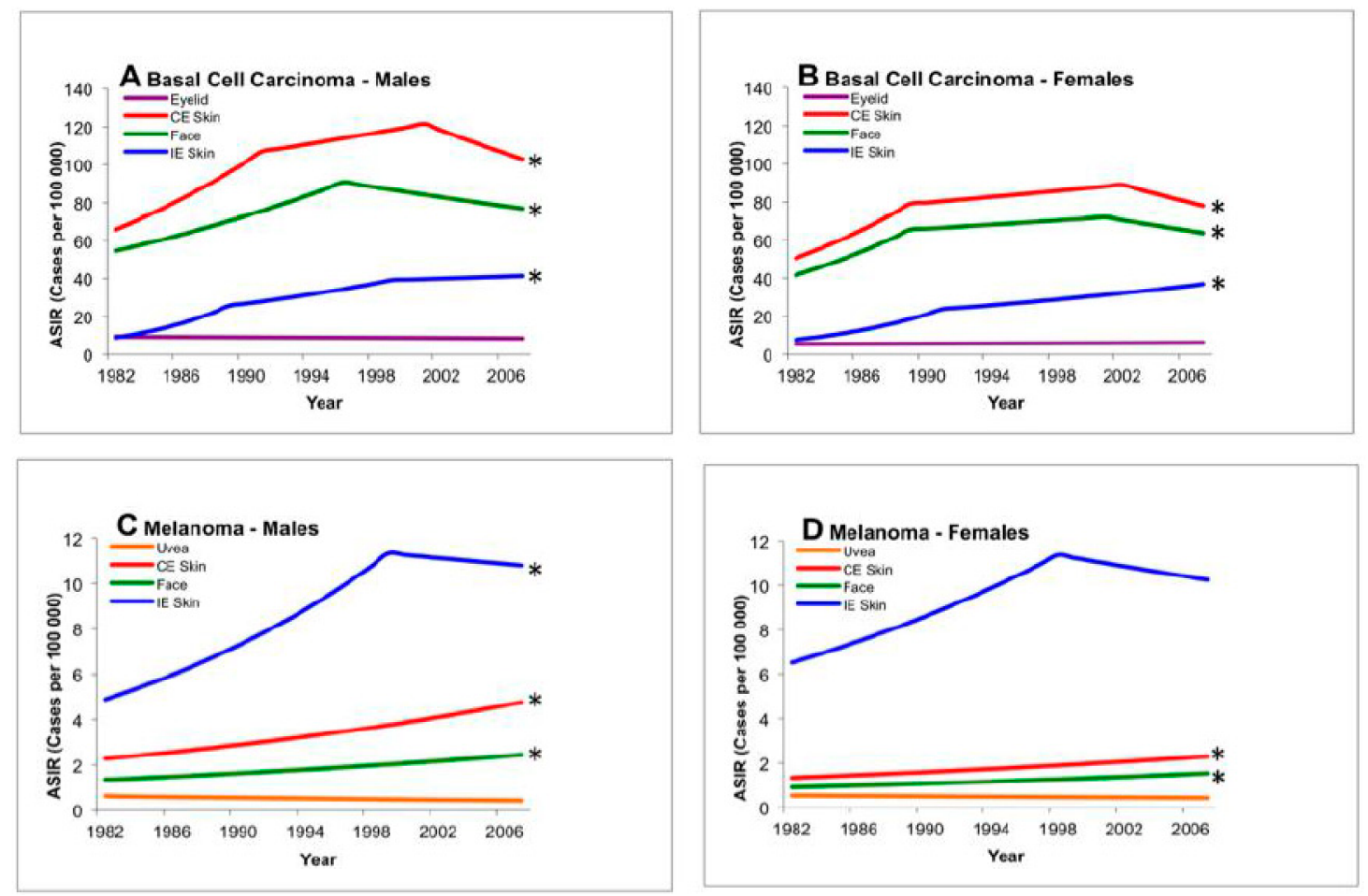

Figure 1. Test of parallelism comparing incidence trends of ocular and cutaneous tumors using registry data, 1982-2007. There is a statistically significant rising incidence in basal carcinoma and cutaneous melanoma of the face, intermittently exposed skin, and chronically exposed skin when compared to uveal melanoma or basal carcinoma of the eyelid. * Denotes non-parallel trend from baseline (eyelid or uvea, $p<0.05$ ). ASIR: age-standardized incidence rate; CE: chronically exposed; IE: intermittently exposed.

For melanoma, tests of parallelism comparing incidence trends for UM versus CM found significantly different rates of change. These changes were statistically significant for chronically exposed skin (Figure 2: males $p=0.001$; females $p=0.04$ ), the face (Figure 2: males $p=0.0002$ and 
females $p=0.0002$ ), and intermittently exposed skin (Figure 2: males $p=0.005$ ). As mentioned previously, the rarity of $\mathrm{CM}$ of the eyelid precluded statistical analysis.

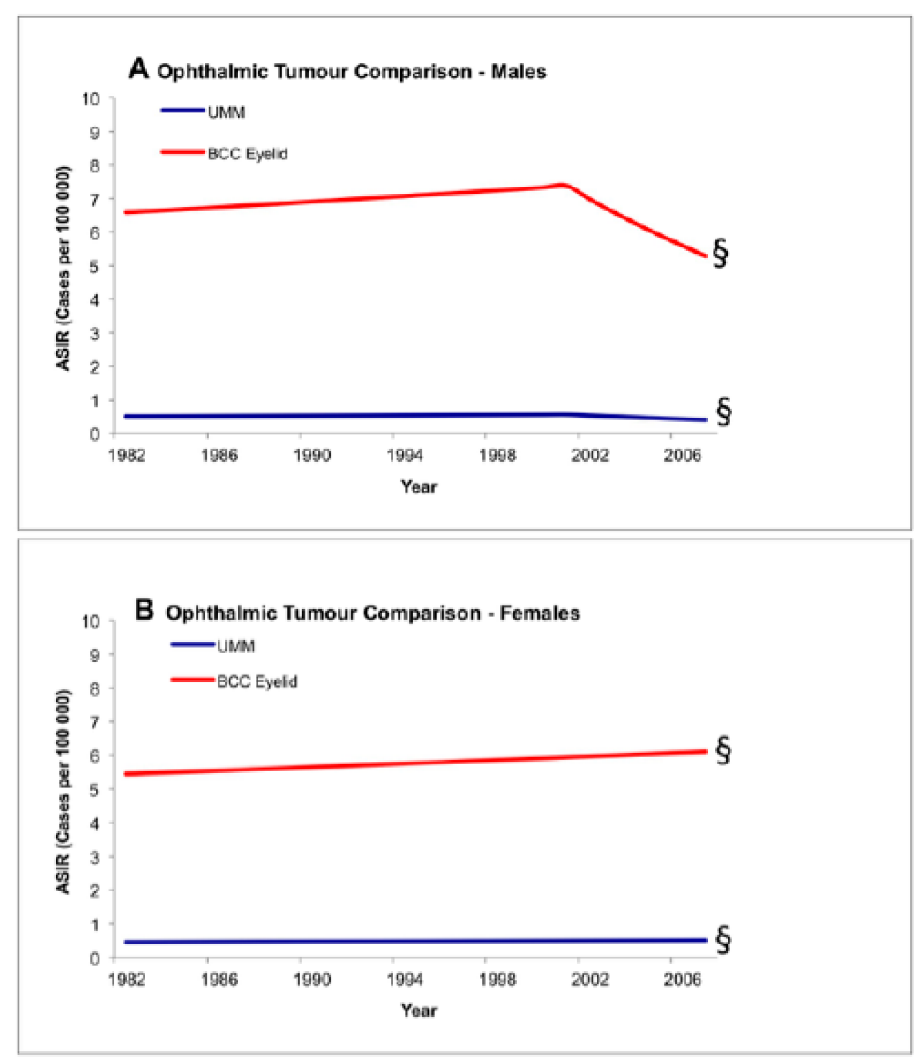

Figure 2. Test of parallelism comparing incidence trends between ocular tumors using registry data, 1982-2007. There is no statistically significant increase in the incidence of basal carcinoma of the eyelid and uveal melanoma. $\S$ Denotes parallel trend $(p<0.05)$. ASIR: age-standardized incidence rate; BCC: basal cell carcinoma; UMM: uveal malignant melanoma.

An additional test of parallelism was performed within the ocular groupings, comparing incidence trends between UM and BCC of the eyelid. Incidence changes between UM and BCC of the eyelid were not statistically different/occurred in parallel (Figure 2: males $p=0.08$ and females $p=0.24$ ).

\section{Discussion}

As sun exposure behaviors have changed, a strong association between the increasing incidence of cutaneous malignancies and UVR has been documented [11,12,33,34]. However, for UM, the absence of a similar increase in incidence over the same time period has been used as a principle argument against its association with UVR [11,12,35-37]. The validity of this argument is based on the premise that comparable increases in UVR exposure have occurred in the ocular region as in the rest of the body. Our study, utilizing the well-established association between BCC of the skin and UVR, developed a proxy variable that allowed for the assessment of changes in UVR exposure to the peri-ocular versus extra-ocular regions.

UM is often considered as a single "intra-ocular" entity, yet it consists of three separate topographical locations including the choroid, ciliary body, and iris. All topographies have the neural-crest derived melanocyte within their cellular make-up, and thus carry its malignant potential. Choroidal melanoma comprises the majority $(80 \%)$ of cases, followed by the ciliary body, and then the iris $[11,12,42]$. Due to its location behind the pigmented iris, the ciliary body likely receives significantly less UVR exposure [31,43], and therefore is less likely to be associated with UVR (Figure 3). Accordingly, its incidence would not be expected to vary with changing UVR exposure patterns. Unfortunately, 
ICD-O codes do not differentiate between the iris and ciliary body (C69.4). Thus, in an attempt to directly evaluate the role of UVR on exposed intra-ocular structures, only cases of choroidal melanoma were included in the analysis.

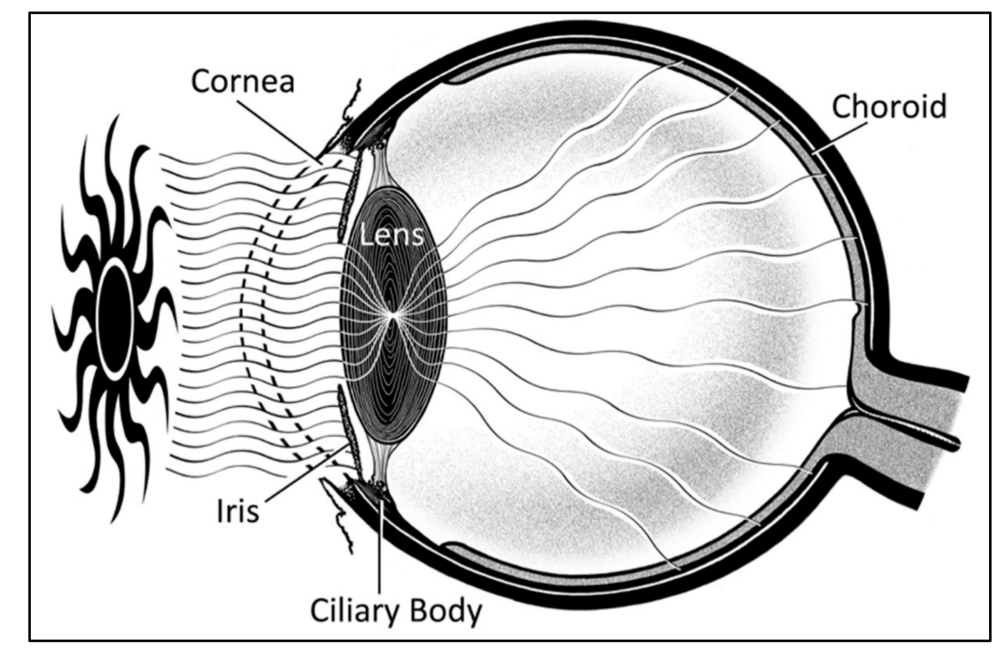

Figure 3. Sagittal schematic of the eye demonstrating ultraviolet exposure of iris and choroid, with sparing of the ciliary body due to protection by the iris.

We report a stable trend in the incidence of eyelid BCC; however, there were upward trends for non-eyelid BCC (chronically and intermittently exposed skin, and the face). This divergence suggests that the ocular region displays a differential and unique exposure pattern to ultraviolet radiation that was not subject to the same increases seen in other body sites.

In a similar manner, incidence rates of UM were compared to rates of CM in non-ocular sites. Mirroring the eyelid BCC results, UM was found to have a stable incidence rate throughout the study period, while CM incidence increased in chronically and intermittently exposed skin. Incidence rates of eyelid BCC group were then directly compared to those of UM, revealing no statistical difference in the change of incidence rates over the study period.

Prior research is consistent with the findings of this study, although there has been no previous study quantitatively comparing peri-ocular malignancies to other anatomical locations [44-48]. A large population-based study in the United States analyzed incidence rates for BCC and squamous cell carcinoma during the years 1972-1973 and 1977-1978 and found that the incidence of both tumors increased in nearly all sites, with the exception of the eyelid, which appeared to be decreasing [44]. A registry-based study in the Netherlands (1975-1988) reported a fluctuating pattern of BCC incidence in the eyelids of females, while increases were observed for the face, neck, and scalp [45]. A large population-based study in Finland (1953-1997) reported an average increase of eyelid BCC over its entire period; however, incidence rates stabilized and began to decrease after 1983 [46]. Similarly, a smaller registry study from Singapore (1968-1995) also reported an average increase in all eyelid tumors ( $84 \%$ basal cell carcinoma) over the entire study period, but rates stabilized for males after 1978 and for females after 1983 [47]. Although not specific to BCC, a long-term registry-study in Sweden (1960-2004) found evidence of another UVR-implicated tumor-squamous cell carcinoma-increasing in all skin sites except the eyelid [48].

Although no formal statistical comparisons between UM and CM trends have been performed, several reports have suggested a difference [11,12], consistent with the findings of this study. A large population-based study from the United States (1974-1998) reported a stable annual percent change of UM incidence, while the incidence of CM increased significantly for both chronically exposed skin (face and ears, scalp and neck) and intermittently exposed skin (trunk and limbs) [11]. Similarly, a registry study from Denmark (1943-1997) reported a stable trend in the incidence of UM, with an increasing rate of CM in all skin sites, including the skin of the face, neck, and scalp [12]. 
Independent of cancer incidence studies, the notion that the ocular region displays a unique exposure pattern is furthered by a series of manikin, in vivo, and computational UVR studies [49-54]. Several investigators have employed manikins equipped with solar dosimeters localized across anatomical regions to quantify UVR doses, finding that the ocular region displayed relatively lower exposures compared to other parts of the face $[49,50]$. Using similar methods, others have demonstrated substantial variability of ocular UVR exposure depending on the use of hats and eyewear and environmental surface reflectivity [51,52]. Another study used computational methods to model UVR exposure at higher resolutions, revealing the importance of reflective properties intrinsic to the anatomy of the peri-ocular structures, calling into question prior dosimetry studies [53]. A review article summarized that the ocular region is different from the skin in other areas secondary to an increased component of reflected and scattered light, peak exposure varying due to the primary role of incident light, the protective effects of the geometry of the face, and back reflection from eye and sunglasses [54]. Although not affecting the eyelid, research has demonstrated that no UV light can pass through the lens after the age of 20 [26]. Taken together, these exposure studies suggest that ocular UVR exposure is unique and affected by many factors [55].

The strengths of this study included the use of high-quality registry data that covers a large population, and the novel approach of using eyelid BCC - the most common eyelid malignancy in Caucasian populations [56]—as a surrogate marker for UVR exposure to the ocular region. Although unlikely to bias our analyses, one limitation of our study was the exclusion of registry data classified topographically as "skin, not otherwise specified" and "overlapping lesion of the skin"; 242 cases of CM and 2343 cases of BCC were coded as such, and would have amounted to only $3.0 \%$ and $3.1 \%$ of the total number of cases, respectively. Another limitation is the absence of other relevant intra-ocular and ocular-adnexal tumors in our study, namely malignant melanoma of the eyelid, conjunctiva, and iris; these tumors were too rare to be subject to analysis, or the data were unavailable.

\section{Materials and Methods}

Research adhered to the tenets of the Declaration of Helsinki. Institutional Review Board approval was obtained.

\subsection{The Alberta Cancer Registry}

Alberta is a province in Western Canada with a population of 3.7 million [57]. It has a universal government-payer-based health care system and provincial cancer agency, providing care for all residents of the province. The Alberta Cancer Registry has been awarded gold certification from the North American Association of Central Cancer Registries for their 2006 incidence data based on completeness, timely reporting, and other measures of data quality [58].

\subsection{Data Selection and Age Standardization}

Cancer incidence data were collected over a 26-year period (1982-2007) for cutaneous BCC and cutaneous and uveal melanoma. Topographic areas were categorized to assess our hypothesis and acknowledge and allow comparisons with prior research differentiating incidence rates of various anatomical regions and their association with UV exposure. The following categories were retrieved (Table 4): uvea (choroid), eyelid, chronically exposed skin (lip, ear, scalp, neck, face including nose), unspecified parts of the face (not eyelid, lip, ear, scalp, neck), and intermittently exposed skin (trunk, limbs). Only malignant neoplasms stated or presumed to be primary (behavior code 3) were included (Table 3). UM is often considered as a single "intra-ocular" entity, yet it consists of three separate topographical locations, including the choroid, ciliary body, and iris. The age-standardized incidence rate (ASIR) was calculated separately for males and females, using the direct method with the United States year 2000 standard population [59]. Annual Alberta population figures by age and sex were obtained from the provincial government ministry of health. Non-Alberta residents were excluded 
from the dataset. Ethics approval was obtained from the Alberta Cancer Research Ethics Committee, and the approval file was received.

Table 4. Topographical and morphological tumor groups for data retrieval, using the International Classification of Diseases for Oncology, 3rd Edition (ICD-O-3) histologic criteria.

\begin{tabular}{|c|c|c|c|}
\hline Name & ICD-O Code & ICD-O Category & ICD-O Description \\
\hline \multicolumn{4}{|c|}{ Topographical group criteria } \\
\hline Uvea & C69.3 & Eye and adnexa & Choroid \\
\hline Eyelid & C44.1 & Skin & Eyelid \\
\hline $\begin{array}{l}\text { Chronically } \\
\text { exposed skin }\end{array}$ & C44.0, C44.2-C44.4 & Skin & $\begin{array}{l}\text { Skin of lip NOS, external ear, skin of other and } \\
\text { unspecified parts of the face, skin of scalp and neck }\end{array}$ \\
\hline Face & C44.3 & Skin & Skin of other and unspecified parts of the face \\
\hline $\begin{array}{l}\text { Intermittently } \\
\text { exposed skin }\end{array}$ & C44.5-C44.7 & Skin & $\begin{array}{l}\text { Skin of trunk, skin of upper limb and shoulder, skin of } \\
\text { lower limb and hip }\end{array}$ \\
\hline \multicolumn{4}{|c|}{ Morphological tumor criteria } \\
\hline $\begin{array}{l}\text { Basal cell } \\
\text { carcinoma }\end{array}$ & $\begin{array}{l}8090 / 3-8094 / 3,8097 / 3 \\
8098 / 3\end{array}$ & $\begin{array}{l}\text { Basal cell } \\
\text { neoplasms }\end{array}$ & $\begin{array}{l}\text { Basal cell carcinoma, NOS; multifocal superficial basal } \\
\text { cell carcinoma; infiltrating basal cell carcinoma, NOS; } \\
\text { basal cell carcinoma, fibroepithelial; basosquamous } \\
\text { carcinoma; basal cell carcinoma, nodular; adenoid basal } \\
\text { cell carcinoma }\end{array}$ \\
\hline $\begin{array}{l}\text { Malignant } \\
\text { melanoma }\end{array}$ & $\begin{array}{l}8720 / 3-8723 / 3,8730 / 3 \\
8740 / 3-8746 / 3,8761 / 3 \\
8770 / 3-8774 / 3,8780 / 3\end{array}$ & $\begin{array}{l}\text { Nevi and } \\
\text { melanomas }\end{array}$ & $\begin{array}{l}\text { Malignant melanoma, NOS; nodular melanoma; balloon } \\
\text { cell melanoma; malignant melanoma, regressing; } \\
\text { amelanotic melanoma; malignant melanoma in } \\
\text { junctional nevus; malignant melanoma in precancerous } \\
\text { melanosis; lentigo maligna melanoma; superficial } \\
\text { spreading melanoma; acral lentiginous melanoma, } \\
\text { malignant; desmoplastic melanoma, malignant; mucosal } \\
\text { lentiginous melanoma; malignant melanoma in giant } \\
\text { pigmented nevus; mixed epithelioid and spindle cell } \\
\text { melanoma; epithelioid cell melanoma; spindle cell } \\
\text { melanoma, NOS; spindle cell melanoma, type A; spindle } \\
\text { cell melanoma, type B; blue nevus, malignant }\end{array}$ \\
\hline
\end{tabular}

Only choroidal melanomas were included in this study.

\subsection{Joinpoint and the Comparability Test for Differences between Groups}

Statistical analysis was performed with the Joinpoint Regression Program (National Cancer Institute, Version 3.4.3) [60,61]. Briefly, for each tumor grouping's log-linear model, an average annual percent change (AAPC) in incidence was calculated for the entire study period [62]. AAPCs are a weighted average of the final model's individual trend segments, with a 95\% confidence interval based on a normal distribution that shows if the average trend is significant (increasing or decreasing) or non-significant from zero (stable). A comparability test known as the test of parallelism [63] was performed in Joinpoint to contrast incidence trend data between different anatomical groupings. The significance level was set at $p<0.05$.

\section{Conclusions}

The controversial association between UVR and UM has not yet been resolved. A primary argument against this association is the observation that while $\mathrm{CM}$ time trends in incidence have risen with increasing UV exposure in the past decades, UM rates have remained stable. This argument assumes that changes in UVR exposure patterns of the ocular region are similar to those of the cutaneous regions that have driven the increasing incidence rates. The results of our study refute this premise by demonstrating that the ocular region has not been subject to an increase in UVR exposure with changing sun behavior patterns. 
Author Contributions: Conceptualization, M.B.P., E.W.; Data Curation, E.W., S.V., D.B.L., M.B.P., J.S. and C.L.S.; Formal analysis, E.W., S.Q.V., D.B.L., J.S. and C.L.S.; Investigation, E.W.; Methodology, E.W. and M.B.P.; Writing—original draft, E.W., S.Q.V., D.B.L. and M.B.P.; Writing—review and editing, E.W., J.S., C.L.S. and M.B.P.

Funding: This research was funded by the Canadian Institutes for Health Research Professional Student Research Award, Health Quality Council of Alberta Student Research Award, the Canadian National Institute of the Blind, and the Dorothy and George O'Neill Eye Research Fund.

Acknowledgments: This study was supported by grants from the Health Quality Council of Alberta, the Canadian Institutes of Health Research, Canadian National Institute of the Blind, and the Dorothy and George O'Neill Eye Research Fund.

Conflicts of Interest: The authors declare no conflict of interest.

\section{References}

1. Gamel, J.W.; McLean, I.W.; McCurdy, J.B. Biologic distinctions between cure and time to death in 2892 patients with intraocular melanoma. Cancer 1993, 71, 2299-2305. [CrossRef]

2. Kujala, E.; Makitie, T.; Kivela, T. Very long-term prognosis of patients with malignant uveal melanoma. Invest. Ophthalmol. Vis. Sci. 2003, 44, 4651-4659. [CrossRef] [PubMed]

3. Chang, A.E.; Karnell, L.H.; Menck, H.R. The National Cancer Data Base report on cutaneous and noncutaneous melanoma: A Summary of 84,836 cases from the past decade. The American College of Surgeons Commission on Cancer and the American Cancer Society. Cancer 1998, 83, 1664-1678. [CrossRef]

4. Kaliki, S.; Shields, C.L. Uveal melanoma: Relatively rare but deadly cancer. Eye 2017, 31, 241-257. [CrossRef]

5. Shields, J.A.; Shields, C.L. Posterior Uveal Melanoma: Management. In Intraocular Tumors: An. Atlas and Textbook. Rev.; Lippincott Williams \& Wilkins: Philadelphia, PA, USA, 1999; pp. 140-175.

6. Singh, A.D.; Bergman, L.; Seregard, S. Uveal melanoma: Epidemiologic aspects. Ophthalmol. Clin. N. Am. 2005, 18, 75-84. [CrossRef]

7. National Institutes of Health Summary of the Consensus Development Conference on Sunlight, Ultraviolet Radiation, and the Skin. Bethesda, Maryland, May 8-10, 1989. Consensus Development Panel. J. Am. Acad. Dermatol. 1991, 24, 608-612.

8. IARC monographs on the evaluation of carcinogenic risks to humans. Solar and ultraviolet radiation. IARC Monogr. Eval. Carcinog. Risks Hum. 1992, 55, 1-316.

9. Gilchrest, B.A.; Eller, M.S.; Geller, A.C.; Yaar, M. The pathogenesis of melanoma induced by ultraviolet radiation. N. Engl. J. Med. 1999, 340, 1341-1348. [CrossRef]

10. Leiter, U.; Garbe, C. Epidemiology of melanoma and nonmelanoma skin cancer-The role of sunlight. Adv. Exp. Med. Biol. 2008, 624, 89-103.

11. Inskip, P.D.; Devesa, S.S.; Fraumeni, J.F., Jr. Trends in the incidence of ocular melanoma in the United States, 1974-1998. Cancer Causes Control 2003, 14, 251-257.

12. Isager, P.; Osterlind, A.; Engholm, G.; Heegaard, S.; Lindegaard, J.; Overgaard, J.; Storm, H.H. Uveal and conjunctival malignant melanoma in Denmark, 1943-1997: Incidence and validation study. Ophthalmic Epidemiol. 2005, 12, 223-232. [CrossRef] [PubMed]

13. Singh, A.D.; Rennie, I.G.; Seregard, S.; Giblin, M.; McKenzie, J. Sunlight exposure and pathogenesis of uveal melanoma. Surv. Ophthalmol. 2004, 49, 419-428. [CrossRef]

14. Swerdlow, A.J. Epidemiology of Chronic Disease Risks in Relations to Ultraviolet Radiation Exposure. Radiat. Prot. Dosimet. 2000, 91, 19-23. [CrossRef]

15. Young, T.A.; Seddon, J.M. Choroidal and cutaneous melanoma: Distinctly different cousins. Ophthalmic Epidemiol. 2005, 12, 221-222. [CrossRef]

16. Shah, C.P.; Weis, E.; Lajous, M.; Shields, J.A.; Shields, C.L. Intermittent and chronic ultraviolet light exposure and uveal melanoma: A meta-analysis. Ophthalmology 2005, 112, 1599-1607. [CrossRef] [PubMed]

17. Weis, E.; Shah, C.P.; Lajous, M.; Shields, J.A.; Shields, C.L. The association between host susceptibility factors and uveal melanoma: A meta-analysis. Arch. Ophthalmol. 2006, 124, 54-60. [CrossRef] [PubMed]

18. Weis, E.; Shah, C.P.; Lajous, M.; Shields, J.A.; Shields, C.L. The association of cutaneous and iris nevi with uveal melanoma: A meta-analysis. Ophthalmology 2009, 116, 536-543.e2. [CrossRef] 
19. IARC Working Group on the Evaluation of Carcinogenic Risk to Humans. Radiation. Lyon (FR): International Agency for Research on Cancer; 2012. (IARC Monographs on the Evaluation of Carcinogenic Risks to Humans, No. 100D.) SOLAR AND ULTRAVIOLET RADIATION. Available online: https://www-ncbi-nlmnih-gov.ezproxy.lib.ucalgary.ca/books/NBK304366/ (accessed on 1 May 2019).

20. Welding, I.A.R.C. Molybdenum Trioxide, and Indium Tin Oxide. IARC Monogr. Eval. Carcinog. Risks Hum. 2018, 118, 36-265.

21. Yam, J.C.; Kwok, A.K. Ultraviolet light and ocular diseases. Int. Ophthalmol. 2014, 34, 383-400. [CrossRef] [PubMed]

22. Gandini, S.; Sera, F.; Cattaruzza, M.S.; Pasquini, P.; Abeni, D.; Boyle, P.; Melchi, C.F. Meta-analysis of risk factors for cutaneous melanoma: I. Common and atypical naevi. Eur. J. Cancer 2005, 41, 28-44. [CrossRef]

23. Gandini, S.; Sera, F.; Cattaruzza, M.S.; Pasquini, P.; Picconi, O.; Boyle, P.; Melchi, C.F. Meta-analysis of risk factors for cutaneous melanoma: II. Sun exposure. Eur. J. Cancer 2005, 41, 45-60. [CrossRef]

24. Gandini, S.; Sera, F.; Cattaruzza, M.S.; Pasquini, P.; Zanetti, R.; Masini, C.; Melchi, C.F. Meta-analysis of risk factors for cutaneous melanoma: III. Family history, actinic damage and phenotypic factors. Eur. J. Cancer 2005, 41, 2040-2059. [CrossRef] [PubMed]

25. Cress, R.D.; Holly, E.A. Incidence of cutaneous melanoma among non-Hispanic whites, Hispanics, Asians, and blacks: An analysis of California cancer registry data, 1988-1993. Cancer Causes Control 1997, 8, 246-252. [CrossRef]

26. Glickman, R.D. Ultraviolet phototoxicity to the retina. Eye Contact Lens 2011, 37, 196-205. [CrossRef]

27. Johansson, P.; Aoude, L.G.; Wadt, K.; Glasson, W.J.; Warrier, S.K.; Hewitt, A.W.; Ingvar, C. Deep sequencing of uveal melanoma identifies a recurrent mutation in PLCB4. Oncotarget 2016, 7, 4624. [CrossRef]

28. Rivolta, C.; Royer-Bertrand, B.; Rimoldi, D.; Schalenbourg, A.; Zografos, L.; Leyvraz, S.; Moulin, A. UV light signature in conjunctival melanoma; not only skin should be protected from solar radiation. J. Hum. Genet. 2016, 61, 361-362. [CrossRef] [PubMed]

29. Royer-Bertrand, B.; Torsello, M.; Rimoldi, D.; El Zaoui, I.; Cisarova, K.; Pescini-Gobert, R.; Raynaud, F.; Zografos, L.; Schalenbourg, A.; Speiser, D.; et al. Comprehensive genetic landscape of uveal melanoma by whole-genome sequencing. Am. J. Hum. Genet. 2016, 99, 1190-1198. [CrossRef]

30. Pandiani, C.; Béranger, G.E.; Leclerc, J.; Ballotti, R.; Bertolotto, C. Focus on cutaneous and uveal melanoma specificities. Genes Dev. 2017, 31, 724-743. [CrossRef]

31. De Lange, M.J.; Razzaq, L.; Versluis, M.; Verlinde, S.; Dogrusöz, M.; Böhringer, S.; Marinkovic, M.; Luyten, G.P.; de Keizer, R.J.; de Gruijl, F.R.; et al. Distribution of GNAQ and GNA11 Mutation Signatures in Uveal Melanoma Points to a Light Dependent Mutation Mechanism. PLoS ONE 2015, 10, e0138002. [CrossRef]

32. Mallet, J.D.; Gendron, S.P.; Drigeard Desgarnier, M.C.; Rochette, P.J. Implication of ultraviolet light in the etiology of uveal melanoma: A review. Photochem. Photobiol. 2014, 90, 15-21. [CrossRef]

33. Bulliard, J.L.; Cox, B.; Semenciw, R. Trends by anatomic site in the incidence of cutaneous malignant melanoma in Canada, 1969-1993. Cancer Causes Control 1999, 10, 407-416. [CrossRef]

34. Jemal, A.; Devesa, S.S.; Hartge, P.; Tucker, M.A. Recent trends in cutaneous melanoma incidence among whites in the United States. J. Natl. Cancer Inst. 2001, 93, 678-683. [CrossRef]

35. Singh, A.D.; Topham, A. Incidence of uveal melanoma in the United States: 1973-1997. Ophthalmology 2003, 110, 956-961. [CrossRef]

36. Swerdlow, A.J. Epidemiology of eye cancer in adults in England and Wales, 1962-1977. Am. J. Epidemiol. 1983, 118, 294-300. [CrossRef]

37. Virgili, G.; Gatta, G.; Ciccolallo, L.; Gatta, G.; Ciccolallo, L.; Capocaccia, R.; Biggeri, A.; Crocetti, E.; Lutz, J.M.; Paci, E. EUROCARE Working Group. Incidence of uveal melanoma in Europe. Ophthalmology 2007, 114, 2309-2315. [CrossRef]

38. Vajdic, C.M.; Kricker, A.; Giblin, M.; McKenzie, J.; Aitken, J.; Giles, G.G.; Armstrong, B.K. Incidence of ocular melanoma in Australia from 1990 to 1998. Int. J. Cancer 2003, 105, 117-122. [CrossRef]

39. Bergman, L.; Seregard, S.; Nilsson, B.; Ringborg, U.; Lundell, G.; Ragnarsson-Olding, B. Incidence of uveal melanoma in Sweden from 1960 to 1998. Invest. Ophthalmol. Vis. Sci. 2002, 43, 2579-2583.

40. Armstrong, B.K.; Kricker, A. The epidemiology of UV induced skin cancer. J. Photochem. Photobiol. B 2001, 63, 8-18. [CrossRef]

41. Hurst, E.A.; Harbour, J.W.; Cornelius, L.A. Ocular melanoma: A review and the relationship to cutaneous melanoma. Arch. Dermatol. 2003, 139, 1067-1073. [CrossRef] 
42. McLaughlin, C.C.; Wu, X.C.; Jemal, A.; Martin, H.J.; Roche, L.M.; Chen, V.W. Incidence of noncutaneous melanomas in the U.S. Cancer 2005, 103, 1000-1007. [CrossRef]

43. Hu, D.N. Photobiology of ocular melanocytes and melanoma. Photochem. Photobiol. 2005, 81, 506-509. [CrossRef] [PubMed]

44. Scotto, J.; Fears, T.R.; Fraumeni, J.F.; National Cancer Institute; Fred Hutchinson Cancer Research Center. Incidence of nonmelanoma skin cancer in the United States prepared by Joseph Scotto, Thomas, R. Fears, and Joseph, F. Fraumeni; in collaboration with Fred Hutchinson Cancer Research Center [et al.]. U.S. Dept. of Health and Human Services, Public Health Service, National Institutes of Health, National Cancer Institute: Bethesda, MD, USA, 1983. Available online: https://search.library.wisc.edu/catalog/999552700102121 (accessed on 1 May 2019).

45. Coebergh, J.W.; Neumann, H.A.; Vrints, L.W.; van der Heijden, L.; Meijer, W.J.; Verhagen-Teulings, M.T. Trends in the incidence of non-melanoma skin cancer in the SE Netherlands 1975-1988, A registry-based study. Br. J. Dermatol. 1991, 125, 353-359. [CrossRef] [PubMed]

46. Paavilainen, V.; Tuominen, J.; Pukkala, E.; Saari, K.M. Basal cell carcinoma of the eyelid in Finland during 1953-1997. Acta. Ophthalmol. Scand. 2005, 83, 215-220. [CrossRef] [PubMed]

47. Lee, S.B.; Saw, S.M.; Au Eong, K.G.; Chan, T.K.; Lee, H.P. Incidence of eyelid cancers in Singapore from 1968 to 1995. Br. J. Ophthalmol. 1999, 83, 595-597. [CrossRef] [PubMed]

48. Dal, H.; Boldemann, C.; Lindelof, B. Trends during a half century in relative squamous cell carcinoma distribution by body site in the Swedish population: Support for accumulated sun exposure as the main risk factor. J. Dermatol. 2008, 35, 55-62. [CrossRef] [PubMed]

49. Diffey, B.L.; Tate, T.; Davis, A. Solar dosimetry of the face: The relationship of natural ultraviolet radiation exposure to basal cell carcinoma localisation. Phys. Med. Biol. 1979, 24, 931-939. [CrossRef]

50. Downs, N.; Parisi, A. Measurements of the anatomical distribution of erythemal ultraviolet: A study comparing exposure distribution to the site incidence of solar keratoses, basal cell carcinoma and squamous cell carcinoma. Photochem. Photobiol. Sci. 2009, 8, 1195-1201. [CrossRef]

51. Rosenthal, F.S.; Safran, M.; Taylor, H.R. The ocular dose of ultraviolet radiation from sunlight exposure. Photochem. Photobiol. 1985, 42, 163-171. [CrossRef]

52. Rosenthal, F.S.; Phoon, C.; Bakalian, A.E.; Taylor, H.R. The ocular dose of ultraviolet radiation to outdoor workers. Invest. Ophthalmol. Vis. Sci. 1988, 29, 649-656.

53. Birt, B.; Cowling, I.; Coyne, S.; Michael, G. The effect of the eye's surface topography on the total irradiance of ultraviolet radiation on the inner canthus. J. Photochem. Photobiol. B. 2007, 87, 27-36. [CrossRef]

54. Behar-Cohen, F.; Bailet, G.; de Ayguavives, T.; Garcia, P.O.; Krutmann, J.; Pena-Garcia, P.; Wolffsohn, J.S. Ultraviolet damage to the eye revisited: Eye-sun protection factor (E-SPFß), a new ultraviolet protection label for eyewear. Clin. Ophthalmol. 2014, 8, 87. [CrossRef]

55. Sliney, D.H. Geometrical assessment of ocular exposure to environmental UV radiation-Implications for ophthalmic epidemiology. J. Epidemiol. 1999, 9, S22-S32. [CrossRef]

56. Margo, C.E.; Waltz, K. Basal cell carcinoma of the eyelid and periocular skin. Surv. Ophthalmol. 1993, 38, 169-192. [CrossRef]

57. Population by Year, by Province and Territory. Available online: http://www40.statcan.gc.ca/101/cst01/ demo02a-eng.htm (accessed on 27 December 2010).

58. Canadian Registries Certified in 2009 for 2006 Incidence Data. Available online: http://www.naaccr.org/ Certification/CANCert2006 (accessed on 27 December 2010).

59. Wolfenden, H.H. On the Methods of Comparing the Moralities of Two or More Communities, and the Standardization of Death-Rates. J. R. Stat. Soc. 1923, 86, 399-411. [CrossRef]

60. Kim, H.J.; Fay, M.P.; Feuer, E.J.; Midthune, D.N. Permutation tests for joinpoint regression with applications to cancer rates. Stat. Med. 2000, 19, 335-351. [CrossRef]

61. National Cancer Institute. Statistical Research and Applications Branch. In Joinpoint Regression Program; April 2010; 3.4.3. Available online: https://surveillance.cancer.gov/branches/srab/ (accessed on 27 December 2010). 
62. Clegg, L.X.; Hankey, B.F.; Tiwari, R.; Feuer, E.J.; Edwards, B.K. Estimating average annual per cent change in trend analysis. Stat. Med. 2009, 28, 3670-3682. [CrossRef]

63. Kim, H.J.; Fay, M.P.; Yu, B.; Barrett, M.J.; Feuer, E.J. Comparability of segmented line regression models. Biometrics 2004, 60, 1005-1014. [CrossRef]

(C) 2019 by the authors. Licensee MDPI, Basel, Switzerland. This article is an open access article distributed under the terms and conditions of the Creative Commons Attribution (CC BY) license (http://creativecommons.org/licenses/by/4.0/). 